\title{
6
}

\section{Resentment and the Genealogy of Morals: From Nietzsche to Girard}

What does it mean to be a philosopher of resentment? It means that one is a philosopher of life, emotions, and instincts. It means that one is a psychologist who focuses on human behavior. There can be no philosophy of resentment without a theory of the human.

Being a philosopher of resentment also makes one an ethical thinker. Resentment remains a special emotion in the ethical tradition; and not merely because Nietzsche based his Genealogy of Morals on its place in history. "Resentment" is only the most recent word for revenge, and the problem of revenge enters the ethical tradition at its inception. The appearance of the word, in fact, marks the attempt, especially on Nietzsche's part, to establish a psychological theory of revenge and its representations. Indeed, the fear of revenge may be the emotion that underlies moral philosophy in the West. A society can survive arbitrary acts of violence; it may even withstand warfare, since battle often strengthens the unanimity of a group. But no society can withstand the premeditated and organized violence of revenge because it initiates menacing cycles of conflict from within. Blood feuds, cycles of revenge, and other forms of organized violence endure for generations; as Greek tragedy dramatically illustrates, they place a curse on the house of mankind. 
Nietzsche's theory of resentment focuses on the problem of representation. ${ }^{1}$ It explains how the weak represent the world to save themselves from the strong. The infamous "slave morality" ascribed by Nietzsche to Judeo-Christianity remains in the final analysis a system of representation. In this regard only, the French Nietzscheans are right to view Nietzsche as a theorist of language. But Nietzsche is more than a linguistic structuralist. Nietzsche saw himself as the first psychologist, and that label is meant to contrast sharply with the philological interests of his youth. Indeed, he feared that mankind would believe in God as long as it believed in grammar, and it follows that the death of God should signify the death of language, and not necessarily the death of the human, as the structuralists believe. Nietzsche cannot be a philosopher of resentment and simultaneously proclaim the death of man, and yet recent theory has used Nietzsche to grant special privilege to the linguistic over the human sciences, often rewriting his work as a grammatology. The French critics of Nietzsche find that his originality lies in his "style" or in the early theories of rhetoric positing that truth is only a fiction of the will to power. For them, Nietzsche was first and foremost a rhetorician; his object of inquiry was language, and he wanted little to do with either the social sciences or the idea of the human. ${ }^{2}$

1. General references to Friedrich Nietzsche will be given parenthetically in the text. They include The Gay Science (abbreviated as GS in the text), ed. and trans. Walter Kaufmann (New York: Vintage, 1974), On the Genealogy of Morals and Ecce Homo $(E H)$, ed. and trans. Walter Kaufmann (New York: Vintage, 1967), The Portable Nietzsche (PN), ed. and trans. Walter Kaufmann (New York: Penguin, 1954), and The Will to Power (WP), trans. Walter Kaufmann and R. J. Hollingdale (New York: Vintage, 1968). References to the works of René Girard include Deceit, Desire, and the Novel, trans. Y. Freccero (Baltimore: Johns Hopkins University Press, 1965), "Strategies of Madness" (61-83), "Delirium as System" (84-120), and "The Underground Critic" (36-6o), in To Double Business Bound (Baltimore: Johns Hopkins University Press, 1978), Le Bouc émissaire (Paris: Grasset, 1982), and "Dionysus versus the Crucified," MLN 99.4 (1984): 816-35.

I have found it difficult to express Nietzsche's thought in a nonsexist vocabulary, especially when discussing the idea of the overman. Perhaps it is best not to mask it.

2. For examples of the French influence in Nietzsche studies, see David B. Allison, ed. The New Nietzsche (New York: Delta, 1977); Nietzsche aujourd'hui, 2 vols. (Paris: Union Générale d'Editions, 1973); and "Why Nietzsche Now?" ed. Daniel O'Hara, boundary 29.3 and 10.1 (1981). An examination of Nietzsche's style may be found in Jacques Derrida, Spurs: Nietzsche's Styles, trans. Barbara 
René Girard, the modern critic of violent desire, has recently developed an argument similar to that of the French Nietzscheans, despite his characteristic opposition to their claims. Girard concludes that Nietzsche's theory focuses on the subtle and civilized language of resentment to the exclusion of the far more dangerous desire for vengeance. In a sense, Girard accuses Nietzsche of being overly concerned with the modern representations of revenge, of which resentment is only one, and not with the real object of humanity's problems. The concern with resentment reveals that Nietzsche has been duped by a fascination with the language of revenge, whose mystifying nature always tries to lead its pursuers off the track by offering them interesting diversions. Resentment is the interesting diversion offered to modern philosophy by violence, while real vengeance advances its death grip on us in the form of nuclear politics and terrorism. Resentment, for Girard, is the spirit of revenge half suppressed. Accordingly, Nietzsche's idea that only the reemergence of revenge will call a halt to modern resentment is revenge's diabolical joke.

Human violence, be it called resentful or revengeful, is mainly an issue of representation insofar as language is the principal means through which individuals come to the knowledge of violence. The most significant question for the ethics of criticism remains whether human beings are capable of understanding their own violence; and Nietzsche's theory of resentment and Girard's theory of vengeance agree that mankind cannot penetrate the nature of its aggression. Sharp contrasts exist between their theories of knowledge, but both thinkers end by placing the knowledge of ethics beyond the reach of human intelligence. In Nietzsche, resentment establishes a slave morality that deliberately misinterprets the differences between the strong and the weak. If human difference is truth for Nietzsche, then

Harlow (Chicago: At the University Press, 1979). For an analysis of Nietzsche's early rhetoric, see Paul de Man, "Rhetoric of Tropes," Allegories of Reading (New Haven: Yale University Press, 1979), pp. 103-18. I analyze de Man's reading of Nietzsche in depth in "Paul de Man and the Rhetoric of Selfhood," New Orleans Review 13.1 (1986): 5-9. 
its knowledge is profoundly restricted by resentment, for the slave morality strives to found a democratic and egalitarian society in which human differences are negligible. Only the appearance of the overman, the creature who has overcome humanity's intellectual limitations, preserves Nietzsche's ideal of difference. In Girard, vengeance as a form of mimetic desire creates elaborate mythologies to defeat human understanding and to perpetuate violence; it enflames its victims with the fever of superiority, giving them a special license to persecute others. The end result is self-destruction, a veritable inferno of violence, in which victim and victimizer annihilate each other.

Revenge and resentment create their own perverse mythologies of knowledge, and Nietzsche and Girard agree that they are dangerous theories at best. There are, however, some differences in the ways that Nietzsche and Girard conceive of the danger. Girard perceives an essential association between violence and desire, whereas Nietzsche defines resentment in the absence of a consistent theory of desire. As a result, Nietzsche sometimes believes that resentment can be overcome by human efforts. Another way of expressing this difference would be to say that Girard is writing with the knowledge of Freud, whereas Nietzsche has no reason to discuss unconscious desire. What post-Freudian thinkers would call desire appears in Nietzsche under other names, not because he is repressing desire but because the psychoanalytic tradition of desire has yet to be established. Nietzsche, of course, gives greater weight to the will, whereas nothing like the will can exist within psychoanalysis. The idea of the will in Nietzsche affirms his wish to posit a theory of knowledge. Freudian theory, to the contrary, insistently divides knowledge and desire, for desire in psychoanalysis works essentially on an unconscious level. Any knowledge of desire acquired by the self is always placed at the service of more desire. The light of desire makes it possible only to cast larger shadows.

Has Freud taught modern thinkers to overestimate the significance of desire in psychology? It is easy in a post-Freudian age to accuse Nietzsche of fleeing from a theory of desire for unconscious reasons. Why does no one ever ask why Freud created a 
theory that suppresses the will? The psychoanalytic theory of unconscious desire holds an enormous attraction for the modern sensibility, perhaps because it provides an antidote to its painful self-consciousness. Once the intellect has been reduced to unconscious motivations by modern theories of desire, individuals may disclaim responsibility for the violence of which they are only too aware. ${ }^{3}$

Although there is certainly no reason to doubt the existence of unconscious desires, no one has yet proved that they are either as determinant or as elusive as psychoanalysis tends to portray them. If the unconscious is unknowable, then psychoanalysis as the science of the unconscious collapses in contradiction. Either psychoanalytic theories of desire are produced by unconscious fantasies and understand nothing about desire, or psychoanalysis has a knowledge of desire that contradicts its own theory of the unconscious. Nor can one accept, without acknowledging the possibility of knowing desire, either the value of the psychoanalytic method or its evolution as a social science.

Desire is indeed central to psychology, but Freudian theory accounts for desire in Nietzsche only with difficulty. Nietzsche does not describe desire only in terms of sexual instincts; he describes the volatile passions of daily human struggle. Desire in Nietzsche is not a monolithic structure but is identified with many unbound and conflicting impulses that pertain to everyday activities and individual character: resentment, false hopes, revenge, nausea, disappointment, and emotions of defeat and victory. Furthermore, Nietzsche seems to accept that human desires can be overcome. The many drives directing humanity's emotional state continually contradict each other, establishing a

3. Recent criticism tends to exaggerate Nietzsche's relation to the unconscious by imposing a Freudian reading on it. Since Freud argues that the unconscious cannot say "No!" some theorists believe that Nietzschean affirmation may be read as a pure desire for unconsciousness. Reducing affirmation to an unconscious state denies the power of the will to determine character and to make decisions. In Freud, the existence of the unconscious acts to discharge individuals of their responsibility for violence, whereas Nietzsche views the will to power as the means for individuals to assume the responsibility for violence in a world where God is dead. What makes affirmation essentially tragic is the conscious acceptance of that responsibility and its paradoxes. 
situation where the intellect must exercise its authority and choose sides. In fact, Nietzsche defines character as the ability to exercise consistent choices. It is a matter not of excluding sexual desire from Nietzsche's philosophy but of recognizing that he considers it important to understand the impact of desire on the knowledge of character and social life. For Nietzsche, there is no experience that cannot lead to knowledge. Consequently, desire includes, at least in theory, the possibility of being understood. Modern theorists make the distinction between the Nietzschean and Freudian views of desire difficult to comprehend because they always prefer the latter to the former. They may begin by arguing that Freud represses the influence of Nietzsche, but they usually end by showing how Freudian Nietzsche is, perhaps because psychoanalytic theory grants a semblance of order to Nietzsche's aphoristic thought.

Like his view of human nature, Nietzsche's idea of psychology contains an abundance of contradictions, and his theory of resentment is no exception. At its center resides the opposition between the conscious and unconscious action of willing. French critics of late have acquired the habit of referring to these types as active and reactive, but the terms need the idea of consciousness to make sense because people are reactive in Nietzsche only when they act against others rather than for themselves. Nietzsche's description of the two forms of willing is hardly just, but it is in keeping with his view of religious history. Judeo-Christianity flounders in the reactive and unconscious form of willing called resentment; its usurpation of power from the "honest Greeks" is nothing like a deliberate strategy, but an accident driven by the power of resentment itself. The Jew, for Nietzsche, is clever, but not sufficiently so to defeat the "higher man" in a fair fight.

To understand the power of resentment will require some explanation, notably because Nietzsche himself does not describe it accurately. Nietzsche tends to define resentment as an emotion always directed away from the self toward others, and he is hard put to explain why the culture of resentment has managed to crush those potential overmen who have maintained their autonomy. Suffice it to say for the moment that 
resentment thrives not by focusing on others but by focusing on itself in contrast to others. Resentment gives by its very structure a certain degree of strength to the resentful self because it acts to muster all the self's suffering around itself. Judeo-Christianity's characteristic belief in its own unworthiness is thus a form of self-preoccupation that gives it an advantage over other religious movements.

Despite Nietzsche's claims, the "noble man" does not differ from the Judeo-Christian in his susceptibility to resentment. The difference remains that Nietzsche's potential overman supposedly possesses the strength of will to attain consciousness of his resentment and to use it as a form of knowledge to move beyond its attractions. The overman refuses the easily gained preoccupation with the self given by resentment in favor of the more conscious striving toward perfection called the will to power. Nietzsche argues that the overman wills to be unconscious of his resentful consciousness, whereas the resentful self of Judeo-Christianity is driven unconsciously by the irritating awareness of its own inadequacy. If this attitude appears psychologically unrealistic or unsound, the reason is not merely that self-consciousness is paradoxical. Such criticisms adhere blindly to a Freudian view of desire, in which desire can never be its own theory. The problem with Nietzsche's description of resentment is twofold. The greatest difficulty springs from the arbitrary distinction created between Judeo-Christians and Nietzsche's potential overman. Nietzsche's own portrait of the man of resentment consistently undercuts this difference, because his idea of who is strongest and who is weakest never corresponds with the actual state of affairs. A second and related problem is that resentment serves knowledge in the case of the noble breed, but mythology in the case of the JudeoChristian.

The philosopher of resentment always risks being accused of resenting those whom he identifies as the sources of resentment. In Nietzsche's case, his resentment of Judeo-Christianity is undoubtedly a reality. Nietzsche's argument for the cultural productivity of resentment applies equally to his own philosophical works, which take their energy from his feelings of insignificance in face of the awesome influence of Judeo-Chris- 
tianity and the Romantic movement in his world. The seminal work on resentment, On the Genealogy of Morals, is Nietzsche's "polemic," but readers often forget what he is arguing against and why. They are taken in by the most superficial aspect of Nietzsche's argument and accept the work as a critique of the forms of religious representation that forsake life in favor of an afterlife. But Nietzsche is not really polemicizing against religious conscience and its denial of life; if he were, he would not try to replace it with a tragic theory that also equates life with suffering. The difference between the martyrdoms of Christ and Dionysus, as we shall see, is a matter of interpretation, but in no way does Nietzsche contest the Christian idea that life on this earth is miserable. Rather, Nietzsche is a philosopher polemicizing against the dominant Christian philosophy of his age. His immediate precursors, Kant and Hegel, both owe an enormous debt to Christian thinking. Nietzsche's revolt against JudeoChristianity is in part a quest for intellectual power and personal distinction, and his motivations are similar to those hidden beneath his break with Richard Wagner.

Was Nietzsche so brazen as to believe that he could reverse by himself the great interpretive and philosophical power of JudeoChristianity? He certainly entered the fray with enthusiasm, and modern philosophy now identifies Nietzsche as the grand inquisitor of religion. In intellectual circles, in fact, Nietzsche emerges as the victor, for few modern thinkers continue to believe that religion possesses any theoretical force. Atheism and intellectual life are now married, and Nietzsche has been given the credit for making the match. Yet Nietzsche was hardly an atheist, but a man passionately involved in religious thinking. The idea of the eternal return provides the strongest demonstration of Nietzsche's religious instincts. One may also consider the ease with which Max Scheler, "the catholic Nietzsche," turned Nietzsche's theory of resentment in favor of Christianity. Finally, it would have been profoundly unlike Nietzsche to choose an adversary who was not his equal or better. Nietzsche entered the battle against religion not as an atheist but as a rival philosopher of religion. Similarly, he attacked morality not as an amoralist or an immoralist but as a competing moralist.

On the Genealogy of Morals tells the story of Nietzsche's resent- 
ful antipathy toward Judeo-Christianity, itself supposedly the flower of resentment. If resentment is the emotion of JudeoChristianity, however, Nietzsche risks being seen as a resentful Christian in his attack on the religion of resentment. To expose this paradox, however, is not to succumb to the nihilist discourse of paradox uttered today in the name of Nietzsche; it is rather to identify the debt that Nietzsche owes to the system called Judeo-Christianity. What, then, is Judeo-Christianity as Nietzsche describes it?

Girard provides a most Nietzschean portrayal of Judeo-Christianity in his writings on the Bible. The Bible is the book of innocents and victims. Girard argues that, contrary to other religious forms, Judeo-Christianity always represents and takes the side of the victim. There is never any illusion of guilt associated with victims in the Bible; scripture insists on the innocence of those sacrificed to violence. It was Nietzsche who invented the idea that Judeo-Christianity is a religion for victims. Unlike Girard, however, Nietzsche found the idea repulsive. The great strength of the Bible in Girard's mind remains its loyalty to the weak and innocent of this world. The great flaw of the Bible for Nietzsche lies in its attraction to weakness, and he explicitly rejects its victimary philosophy. Nietzsche's aversion to the images of the suicidal Socrates and of the crucified Christ turns on their presentation of victims as models to emulate. His hatred of Rousseau similarly derives from the sense that the founder of Romanticism was a coward who took delight in self-deprecation, weakness, and complaint.

In reaction, Nietzsche took up his famous warrior stance, a determined resistance to pity for all victims. Being a warrior has the benefits of attracting both wisdom and women. Unfortunately, Nietzsche's success on both counts is hotly contested. What Nietzsche did achieve was a certain courage of conviction in pursuit of self-examination. For a resentful spirit, he was remarkable for his ability to accept responsibility for his ideas and personal choices. Ecce Homo emerges as a kind of funereal statement on Nietzsche's acceptance of his decisions in life and work. It is curiously free of resentment, although Nietzsche never abandons his acerbic and aphoristic manner. The book dem- 
onstrates his sustained effort to combat his own weaknesses, the most pernicious being the proclivity to resentment; he emerges as a victor, at least to the extent that someone of such enormous emotions could. Perhaps his only true rival in tenacious self-confession is Saint Augustine, a man who also knew the temptations of succumbing to both self-delight and peer pressure, as the incident of the stolen pears attests.

Nietzsche's hatred of weakness and disgust for pity seem his most abhorrent traits, especially in a world of Judeo-Christianity. Such traits greatly influenced the Nazis and are responsible in part for Nietzsche's association with them in the popular mind. We tend to forget, however, that the argument against weakness and pity intends to eliminate the kinds of atrocities for which Hitler was infamous. Resentment, in Nietzsche's mind, is repugnant chiefly because it leads people to blame others for their inadequacies. A Nietzschean analysis of Nazi anti-Semitism would name the Jews as scapegoats for the Germans' emotions of inferiority and pain. The resentful self never sees itself as the reason for its sorrows, and it searches feverishly to vent its feelings in accusation. "For every sufferer," Nietzsche insists in the Genealogy, "instinctively seeks a cause of his suffering; more exactly, an agent; still more specifically, a guilty agent who is susceptible to suffering-in short, some living thing upon which he can, on some pretext or other, vent his affects, actually or in effigy" (127). The sufferer's reflex action is to deaden his or her pain, and Nietzsche surmises that this alone "constitutes the actual physiological cause of ressentiment, vengefulness, and the like" (127). The basis of Nietzsche's hatred of resentment is a pessimistic vision of society, in which the suffering poison themselves with their own malice, tear open their oldest wounds, and make "evildoers out of their friends, wives, children, and whoever else stands closest to them" (128).

It is therefore no accident that Nietzsche's most "psychological" work, Thus Spoke Zarathustra, denounces resentment and revenge as obstacles to the emergence of personal health and strength. Although the book is ultimately unsuccessful in its task because it cannot overcome its disgust for mankind, Zarathustra does embody Nietzsche's greatest attempt to de- 
scribe the possibility of knowledge beyond revenge and resentment. It advances a measured theory concerning the psychological strategies available to defeat violent emotions. The achievement of Zarathustra consists in Nietzsche's ability to translate the major terms of his philosophy-resentment, revenge, the will to power, and the eternal return-into models for individual behavior. And as such, each term appears not as a cosmological or philosophical idea but as a principle serving a series of psychological tactics for the formation of character and self-discipline.

"For that man be delivered from revenge," Zarathustra proclaims, "that is for me the bridge to the highest hope, and a rainbow after long storms" (PN 211). Revenge, like resentment, is a secondary form of desire that expresses a need to direct one's view outward instead of back to oneself. But both passions have contradictory effects. They create for the self a temporal continuity between past disappointments and the expectation of violent satisfaction in the future. This temporal continuity involves a certain self-consciousness, but it is a negative self-consciousness, and revenge and resentment end by obstructing the process of self-overcoming that represents the only source of satisfaction in Nietzsche's thought. The desire for revenge may determine the self's continuity and purpose, but ultimately it corrupts the self. It promises a brief taste of honey in exchange for an eternity of bitterness.

Human beings are destined, Nietzsche concludes, to live on the back of a tiger, but they need not live in ignorance. Zarathustra warns about the destructive effects of high expectation, disappointment, and vengefulness. Indeed, Nietzsche believes that the person single-mindedly obsessed by a past wrong is a most gruesome sight. Future expectations are equally dangerous, for they starve to death the person who feeds upon them. In general, desires directed toward the past or future consume the self in a fever and threaten to destroy it. The most sublime seekers of knowledge try to address both their expectations and disappointments, which explains why Nietzsche considers nihilism and asceticism as psychological phases in the process of gaining strength of will. The nihilist clings to nothing- 
ness as a means of voiding past disappointments and of defending against future sorrows. Ascetics extinguish in themselves those desires that they expect will remain unfulfilled in the future. Both are partially successful in protecting themselves against adverse desires as well as in protecting others from their potential resentment. Yet nihilism and asceticism are mere "winter pranks." Like the will to hibernation, the deliberate choice to lose consciousness, they are reactionary attitudes of self-defense that strive, paradoxically, to react as rarely as possible. They are prudent but necessarily incomplete strategies. "Freedom from fever is not yet knowledge by any means!" (PN 402).

Knowledge and freedom appear at first glance to oppose desires for violence, revenge, and accusation, although Nietzsche argues that they represent necessary stages in the process of coming to knowledge. Revenge and accusation are the negative qualities associated with the resounding "No!" of the man of resentment. In The Gay Science, Nietzsche describes accusation as the strongest form of no-saying. At the same time, he embraces amor fati as the essence of affirmation: "Amor fati: let that be my love henceforth! . . I I do not want to accuse; I do not even want to accuse those who accuse. . . Someday I wish to be only a Yes-sayer" (223). Zarathustra associates the nausea of the fool with the desire for revenge. Freedom from nausea is bought only with the courage to pass by: "where one can no longer love," Zarathustra counsels, "there one should pass by" (290). Or, as Nietzsche says in The Gay Science, "Looking away shall be my only negation" (223). Finally, Nietzsche respects Buddhism only because it stands firmly against revenge: "there is nothing in which his doctrine is more opposed than the feeling of revenge, antipathy, ressentiment ('it is not by enmity that enmity is ended' - that is the stirring refrain of Buddhism)" (PN 587-88). Or again in Ecce Homo: "Not by enmity is enmity ended; by friendliness enmity is ended" (230). The desire for revenge represents the great weakness of human character and cultural institutions. It signifies, in Nietzsche's eyes, that we are still lacking in power, that we are succumbing to frustration in the face of our poverty. 
The will to power represents Nietzsche's supreme strategy for defeating resentment. Yet no other doctrine has tended more to cloud the positive aspects of his project. The confusion relates to the changing meaning of the concept in Nietzschean thought. The will to power begins as a negative trait, a lust for power. Soon, however, it acquires a psychological significance. Nietzsche describes the will to power as a process of individual development and strengthening that moves increasingly toward superior judgment and self-awareness. It is the power by which the self effects its own change. The summit of this development arrives with Zarathustra, who counsels people to stand firmly in themselves and to create over and beyond themselves. Finally, Nietzsche associates the will to power with the inexhaustible procreative power of life, which nevertheless strives, like Freud's Todestrieb, to discharge itself.

If the will to power were solely the unleashed procreative power of life, the individual would have little effect on its direction. There would be little space for the self-examination demanded by Zarathustra, and Nietzsche would have praised rather than attacked Darwin. The third phase of the will to power coincides with Nietzsche's emerging madness. It represents the contradictory desire to affirm his omnipotence and to sacrifice himself to cosmic forces. Yet the third phase cannot be attributed entirely to Nietzsche's madness because it remains consistent with his critique of God and causa sui logic. The late doctrine of the will to power does not attribute any effect to a single cause; rather, it describes the world as a complex network of forces, in which force is relational and nothing is its own cause. The totalitarianism of the will to power is dispersed into a range of conflicting impulses. The will to power becomes the essence of self-overcoming (Selbstüberwindung).

For Nietzsche the psychologist, the second phase of the will to power is more crucial. It should not be confused with the lust for power or the will to conquer. The Nazis invented the view of the will to power as a recipe for world mastery, and Walter Kaufmann has shown most effectively that it is really a strategy for self-overcoming and not a justification for war. ${ }^{4}$ The will to

4. Walter Kaufmann, Nietzsche: Philosopher, Psychologist, Antichrist (Princeton: At the University Press, 1968), p. 200. 
power is always directed toward the self, although completely within a social context. Nietzsche was too aware of patterns of prejudice and reciprocal accusations to conceive of it otherwise.

In effect, the will to power represents a form of self-discipline. Cultivation (Zucht), Nietzsche says, requires discipline (Zuchtigung). Man is the embryo of the man of the future, and he requires discipline to develop. "The will," according to Nietzsche, "is precisely that which treats cravings as their master and appoints to them their way and measure" (WP 52). Apparently, the man of the future will be master over his own savagery and licentiousness. The desires will have learned to obey and to be useful. Consequently, the will to power does not release the libido. It strives to economize desires. Walter Kaufmann calls reason the highest manifestation of the will to power because it realizes its objective most fully. ${ }^{5}$ Nietzsche's aesthetics bears out the image of the will as an economy of desire. It defines the ugly as a lack of coordination among inner desires. The beautiful, in contrast, holds in harmony all strong desires. It is reverence without tension, and no violent person can attain the beautiful by exertion.

Greatness of character in Nietzsche's eyes means having all affect under control, but not for the pleasure of mastery. Those who will to will strive to be equal to accidents, allowing themselves neither disappointment nor expectation. They do not pit themselves against probability. They will not to defend themselves against others as the best defense. They are not hedgehogs. They choose not to have quills, but to have open hands.

Although Heidegger's reading of Nietzsche is the cause of much confusion today, his description of the will to power may clarify matters. ${ }^{6}$ He defines the will to power as resolute openness (Ent-schlossenheit). Those who will station themselves among others, but keep themselves open to them. Their traits are not seizure and agitation but an awareness of their emotions and surroundings. Heidegger's remarks cast light on the dangerous opposition between active and reactive often associated with the will to power. He suggests that the will to power is

5. Kaufmann, p. 230.

6. Martin Heidegger, Nietzsche, 2 vols. (Stuttgart: Neske, 1961), 1:59. 
reactive, but not merely reactive; it does not need the accoutrements of battle. Gilles Deleuze bases his reading of Nietzsche on this opposition. ${ }^{7}$ He defines the will to power as active and resentment as reactive. His theory is nevertheless oversimplified. Like the will to hibernation, asceticism, and nihilism, the will to power is reactive in essence. It tries, however, to differ from resentment by economizing reactions. The will to power is a principle of selection. It honors by choosing, admitting, and accepting. It reacts slowly, with a slowness bred by caution and deliberate pride. It does not believe in misfortune or guilt. Most importantly, it learns how to forget.

It is easy to be open toward the future because postponing expectation takes no great strength of will. The greatest danger to the self is the past, for disappointment may transform the will to power into the desire for revenge. The will does not easily learn to forget or to pass by. "This, indeed this alone," Zarathustra concludes, "is what revenge is: the will's ill will against time and its 'it was' " (252). The will has difficulty willing backward, and Nietzsche's description of the will confronted by the "it was" provides a perfect portrait of the man of resentment: "what is it that puts even the liberator himself in fetters? 'It was' - that is the name of the will's gnashing of teeth and most secret melancholy" (251).

How to will backward? This is Nietzsche's most important question, for it places the will to power and resentment in direct confrontation. It requires the heaviest thought: the eternal return. The return is the heaviest burden upon mankind not because it signifies an existential or ontological dilemma but because it requires the self to posit the eternal recurrence of the "it was," which remains the secret melancholy of the will to power. The eternal return conceives of the enormous power of memory as the engine of intersubjective violence. The man of resentment lives his past in the future; he is trapped in the "it was." How can he hope to will without directing his power toward revenge?

The answer is to give the will to power no precise center and to bind it to the eternal wheel of the return. The eternal return

7. Gilles Deleuze, Nietzsche et la philosophie (Paris: PUF, 1967), chap. 2. 
portrays the past as a riddle for the creative will. All "it was" is a fragment, a riddle, a dreadful accident that the creative will must redeem. Redemption has a special meaning for Zarathustra. It describes the process by which the will recovers what is past and re-creates all "it was." As creator, guesser of riddles, and redeemer of accidents, Zarathustra teaches mankind to work on the future and to return for profit to all that has been. The will learns to confront the "it was" and say, "Thus I willed it! Thus I shall will it!" (310).

I am stressing the personal and not the cosmological aspects of the eternal return because Zarathustra first presents it in a psychological context, although there is ultimately little difference in effect between its psychological and religious dimensions. The eternal return prevents the will to power from succumbing to the desire for revenge. It aids the will in the process of self-overcoming, for the focus of the return is the self. What returns, what finally comes back to one who wills the return, is one's own self and those aspects of the self that have been lost in strange lands and scattered among things and accidents.

The doctrine of the eternal return portrays each moment as a gateway where the past and future meet in a decision of the present. It is therefore more than a theory to redeem the past. It places the weight of decision on each moment. "I am the first," Nietzsche says, "who is able to decide" (EH 314). The question posed for each and every moment is, "Do you desire this once more and innumerable times more?" (GS 274). Far from celebrating indecision, therefore, Nietzsche loads each moment of existence with the burden of judgment. The strategy of the return makes the will responsible for its own existence and power. It designs the circle of the will's necessity. The will that wills the eternal return is the will that wills itself and finds itself in the necessity of willing. Nietzsche's theory of the eternal return thus belongs to the ethical tradition, especially to the view of the will established by Kant. The eternal return represents the will as the force that orients understanding not toward a mythical past, here seen as the world of resentment and revenge, but toward an ethical future. Every action stands under the compulsion of causes that are past, while simultaneously calculated 
from the point of view of future ends and their systematic unity. The former sense situates willing within a series of events, whereas in the latter the will belongs to the order of obligation and ideal determination. Kant invented the autonomy of the will as part of his critical ethics, but in Nietzsche it acquires a distinctive psychological emphasis. Nietzsche has different names for the strategy; he calls it la gaya scienza, "tragic wisdom," and amor fati, but each describes a supreme affirmation of life. "If we affirm one single moment," Nietzsche believes, "we thus affirm not only ourselves but all existence. For nothing is self-sufficient. . . . All eternity was needed to produce this one event-and in this single moment of affirmation all eternity was called good, redeemed, justified, and affirmed" (WP 532-33).

To affirm the moment is the opposite of nihilism, which affirms nothing. To be equal to accidents is to defeat disappointment and expectation. Most important, to think the eternal return is to overcome the contempt of the human. At the end of part 3, Zarathustra's animals, the eagle and snake, compose a ditty with their master's words about the eternal return. They churn out the heaviest of all thoughts like barrel organs. Suddenly, a great disgust crawls into Zarathustra's throat, and nausea sticks to his mouth. He chokes on the idea that even the small man, the man of whom he is most weary, recurs eternally. "Alas," he groans, "man recurs eternally!" (331). Zarathustra's nausea means that he does not yet understand the eternal return. Only if he can overcome his sickly contempt for the human and begin to compose his own dancing songs will he know enough about the eternal return to be its prophet.

Nietzsche portrays Zarathrustra as a convalescent, and resentment is the illness from which he is recuperating. Zarathustra feels resentment against his betters, and he resents the small man for continuing to exist. The eternal return, by creating a gateway between the past and the future, deliberately confronts the temporal structure of resentment, presenting a homeopathic remedy for what ails both Nietzsche and his only literary character. Zarathustra begins by oscillating between feelings of superiority and inferiority and between pity and disgust for mankind, and he emerges as a self-parodist and ironist. The ass festival, as the finale of the book, presents the best 
illustration of who Zarathustra has become. The episode represents Zarathustra as a joyful affirmer; yet the parodic attitude directed toward the Last Supper shows that Nietzsche has never strayed far from his resentment of Judeo-Christianity. Zarathustra's great moment of originality is hardly original at all; and Nietzsche's struggle toward freedom triumphs only in the freedom to imitate what he most despises. In this sense, the doctrine of self-overcoming acquires another, more ominous meaning, one that approaches the desire for self-defeat.

The paradox of Zarathustra's "victory" exposes the fatal flaw in Nietzsche's theory of knowledge. Even though much of Zarathustra is directed toward a potent psychological attack on revenge and resentment, its hero never throws off his chains. Such is the case not because the notion of resentment is absolutely incompatible with knowledge-it is clear that Nietzsche presents a viable method for combating the emotions that threaten self-knowledge-but because Nietzsche's characterizations of Zarathustra and the overman are self-destructive. By attributing to them a distinctiveness of will that should belong to mankind in general, Nietzsche represents Zarathustra and the overman as special cases within human destiny. The idea of the repetition of the same remains crucial to the eternal return as Nietzsche describes it, but the overman's difference from others risks corrupting the pattern of the repetition. The overman becomes a living metaphor for the resentment and contempt of the human. Similarly, Nietzsche himself emerges as the resentful parodist of the one religious institution that he wishes to forget. A generous interpretation of the ass festival would point to Nietzsche's idea of amor fati and conclude that Zarathustra finally adopts the only attitude toward Judeo-Christianity possible in the world of resentment - that is, to affirm it. But Nietzsche's mocking attitude betrays his acceptance, and he remains a victim to his antipathy for Judeo-Christianity. What could be a more self-despising image of affirmation than the "Yea-Yuh" of the brainless ass? In the final analysis, Zarathustra is not able to forget, accept, or surpass Judeo-Christianity, and consequently Nietzsche is forced to emulate its victimary stance, however ironically.

The case of the overman represents only a more extreme ex- 
ample of Nietzsche's failure to escape the throes of self-victimization. Like Baudelaire's self-torturing Heautontimoroumenos, the overman is a contradiction in terms, which explains why Nietzsche refused to provide a clear portrait of him. Apparently the overman opposes only his equals. He stands so confident in his superiority that he does not deign to compete with the inferior men of the world. But how long will the overman be able to resist the temptation to swat the gnats flying into his lordly eyes? Sooner or later, a gnat will die under his hand, reducing him, in his own mind, to the level of those most contemptible to him. Or imagine a community of overmen, sublime in their conversation and knowledge, each maintaining their distinctive autonomy and domain. The image of the Elysian Fields comes to mind, but the shepherds of Elysia are dead, and lifeless would be the community of overmen, for Nietzsche defines life as struggle and competition. If the overmen vied with each other in Homeric contest, venting their desires for revenge when necessary, the result would be a parody of Mount Olympus. And one need only read Homer to understand that the Olympic gods are beings who thrive on vanity, rivalry, and a spirit of cruelty that takes sport in destroying lesser creatures. In the end, the overman is crushed by his own weighty desire for superiority. Either he sacrifices his own vitality to prove his mastery, or he becomes a slave to his most violent and primitive instincts.

Zarathustra and the overman emerge as victims of their own will to power, and neither one is capable of forgetting that he is a victim. Nietzsche himself appears as one of the most remarkable examples of an individual who tries to forget his own persecution in a manner that most encourages self-violence. The resentful self always sees itself as a victim, for its moral strength lies in the representation of its persecution to others. The strong relinquish their essential being because the victimary image presented by the resentful self makes them ashamed of their strength. The resentful may then use their sense of victimization to rationalize the most violent persecutions. The weak are stronger for their weakness, and the strong imitate the weak with docile acceptance. But if the resentful self gains strength merely by presenting a victimary attitude, some condition for its 
coming into power must already exist in human society. The victimary attitude must already possess a unique social significance, one for which both the strong and the weak are willing to vie. Nietzsche's theory of the genealogy of morals thus collapses upon itself, for how can resentment be the origin of morality if it needs as a given the special moral status of the victim? Nietzsche's theory of the will to power is at once an attempt to escape this tautology and to posit a spontaneous and sui generis desire to oppose resentment. It represents both Nietzsche's attempt to think exterior to resentment and his desire to stand forth as an autonomous individual.

The ethical significance of the victimary attitude remains the blind spot in Nietzsche's genealogy of morals. Contrary to his intentions, Nietzsche demonstrates that the weak and not the strong hold a privileged role in ethical representation. His ideas are closer to Judeo-Christianity than he wishes, and the theory of resentment emerges as an extreme reaction to the fact. The contradiction appears most evident in his notion of affects. Human suffering itself creates an ethic based on the presence of a victim, for the sufferer looks instinctively to blame his pain on another. Nietzsche makes it clear that the sufferer's logic of cause and effect requires a victim if it is to divert the responsibility for the pain somewhere else. Indeed, Nietzsche's critique of culture is based on his disgust with the morality that needs victims, but this horrified vision of human aggression and cruelty does not yet include the idea of resentment. Resentment in Nietzsche does not refer specifically to human beings' general tendency to harm each other. Resentment is a secondary emotion in Nietzsche, more characteristic of higher cultures, and it emerges as the force behind the new ethics of Judeo-Christianity.

By virtue of its self-conscious nature, resentment serves to alter through a striking process the originary ethic of persecution that Nietzsche identifies with culture. The resentful self makes itself a victim, thereby occupying the role traditionally given to the victim in ethical representation. Resentment is therefore an intuition of the significance attributed to the victim in human culture. The resentful self comes to knowledge nega- 
tively on the basis of its resentment, as Eric Gans brilliantly argues, "for what is intuitively grasped is the self-as-victim, the victim of a social distinction that condemns the self to insignificance" (61). ${ }^{8}$ This self-consciousness makes the resentful self its own center of strength, but it is, paradoxically, a strength based on its own sense of insignificance. The resentful self discovers a secret ratio between weakness and strength, literally creating its own power out of nothing. In this center of strength, its representation of itself as victim, the resentful individual discovers the privileged status of the victim's position at the origin of ethical representation. The cultural productivity that Nietzsche attributes to resentment thus evolves by imitating with a twist the representational patterns of human violence. Indeed, Nietzsche's critique of Judeo-Christianity begins from this proposition. Resentment, he proclaims, creates its moral system by victimizing the strong and noble of the world.

If Nietzsche's genealogy of morals has begun to resemble Girard's theories of violence, it is not because I have dressed a wolf in sheep's clothing. There remain differences between Nietzsche and Girard, most notably the classic distinction established by Nietzsche between his thought and Judeo-Christianity. Rather, the resemblance exists because Girard himself acknowledges that his intellectual precursors are Nietzsche and Freud. Nietzsche especially remains deeply but paradoxically involved in Girard's attempts to illuminate the role played by violence and desire in religious representation. His most recent work on Nietzsche, "Dionysus versus the Crucified," begins by describing as an oblique and somewhat uncourageous version of a larger issue the great debate that raged after the war over Nietzsche's responsibility for the Nazis' exploitation of his writings. For Girard perceives Nietzsche's antichristian polemics, not his relation to Nazism, as the ethical issue on which his work must be either exonerated or condemned. As such, Girard's work stands at one extreme of the notorious opposition

8. Eric Gans, "The Culture of Resentment," Philosophy and Literature 8.1 (1984): 55-66. Gans provides an extremely clear and useful discussion of resentment in which desire and knowledge are not mutually exclusive. I have relied on his remarks throughout this essay. 
between Dionysus and the Crucified, and his career may be best traced through his writings on Nietzsche, just as Nietzsche's thought is best characterized in its opposition to JudeoChristianity.

Girard describes human desire as fundamentally conflictual because it encourages the most mindless imitation. In Girard's definition, desire robs individuals of conscious choices by compelling them to repeat the actions of others, and individuals who desire collide as they vie for objects and repeat each other's tactics of appropriation. Mimetic desire distorts rivals and objects of desire, generating a form of mythology that conceals the true nature of the world. Desire always leads to an explosion of human violence, Girard explains in Violence and the Sacred, to those episodes of general conflict in which individuals randomly imitate each other and end by blaming specific individuals for the existence of disorder. From the heat of the conflict, a scapegoat emerges, and the mob makes him or her responsible for the chaos. The mimetic desire for appropriation metamorphoses into another form of mimetic desire. The group represents the victim as a sign of the crisis, and this representation of responsibility infuses the victim with great power, for to be responsible for an event, one must have had the power to have caused it. Such is the origin of the sacred in Girard's mind. As the sacred becomes increasingly institutionalized, victims are less arbitrary in the sense that they are bred to be sacrificed. Religion uses sacred ritual to commemorate originary scenes of disorder for the purpose of forestalling the emergence of a more random form of violence.

The knowledge of mimetic desire, however, represents the most paradoxical aspect of Girard's theories. Desire in Girard's eyes depends on mankind's unwillingness to free itself from its patterns. Even if they were to understand that the desirability of objects is symbolic only of their own desires for superiority, individuals would continue to struggle for the same object. Nor would an understanding of the blind mechanisms of persecution prevent people from making scapegoats of others. Desire remains essentially unconscious in Girard's work, and the forms of violence generated by it are unknowable in the same sense 
that the Freudian unconscious is unknowable. How, then, has Girard made his discoveries?

In the early Deceit, Desire, and the Novel, literature appears as a source of knowledge. Novels in particular take as their subject the workings of desire. All great novels, in Girard's estimation, end with a conversion, in which both hero and author discover for the first time the eternal web of desire in which they are ensnared. The novel destroys as well the false differences and mythological characteristics attributed to others in the heat of rivalry. The genius of the novel seems to repeat the epiphany of Nietzsche's Beyond Good and Evil, for it "transcends the rival caricatures of Good and Evil presented by factions. It affirms the identity of the opposites on the level of internal mediation. But it does not end in moral relativism. Evil exists. . . . Evil is that negative pact of hatred to which so many men strictly adhere for their mutual destruction" (192).

The remark on moral relativism refers to Nietzsche. Girard reads Nietzsche's work not as a novelistic leap beyond good and evil but as a celebration of relativism and nihilism. Thus Spoke Zarathustra presents a new gospel to mark the end of the Christian gospel; it proposes a new askesis to make God unnecessary. Nietzsche's philosophy is Girard's supreme example of modern thought, in which people strive desperately to fill the void left by the death of God by making gods of themselves and of each other. Modern thought turns away from the revelation of the gospel. "Christ," Girard argues, "sent men in search of God; he gave them a glimpse of eternity" (275). But the feeble fail in their efforts and turn back on humanity, bringing about the tortuous world of hatred, vanity, and envy.

Nietzsche represents the antinovelistic in Girard's early writings, and as the Christian dimension of his theories emerge, Nietzsche truly becomes the antichrist. Deceit, Desire, and the Novel permits an understanding of desire through the reading of great novels; it is fundamentally optimistic and revelatory in character. But Girard's recent work makes it clear that the message of the novel is made possible only through its imitation of Christ's passion. The novel dramatizes the law of antipersecution expressed by Saint Paul's Epistle to the Romans: "Therefore 
thou art inexcusable, $\mathrm{O}$ man, whosoever thou art that judgest: for wherein thou judgest another, thou condemnest thyself; for thou that judgest doest the same things" (74). Novelistic truth in Girard's description remains identical to the Word of Christ and the Bible: it teaches the law of neighborly love and the profound revelation that human beings are equal in hatred and charity.

As the light of revelation grows stronger, however, so does the dark unintelligibility of desire and violence; and Girard's most definitive statements about the unknowability of desire take Nietzsche as their example. "Strategies of Madness," in To Double Business Bound, reduces all of Nietzsche's thought to the blindness of mimetic desire and the rivalry with Wagner. Girard compares Nietzsche's attempts to rewrite the history of his relationship with Wagner in his own favor with the reconstruction of history found in modern dictatorships. Like all modern thought, Nietzsche's will to power encourages "the most selfdefeating behavior" (68). Girard explains that the will to power always collapses into resentment because it deliberately seeks opponents whom it cannot defeat; if the will to power cannot find an insurmountable rival, it will be crushed by indifference. "There is always enough indifference in the world," Girard writes, "to destroy the most powerful will to power" (73). Nietzsche's will to power obeys the theory of mimetic desire, and as such it characterizes the inability of any theory to escape the web of desire. Desire is already its own theory, but its insights return inexorably to desire: "desire learns more and more from its own defeats, but ... it puts this knowledge in the service of more desire, making even more catastrophic defeats inevitable" (74). Any theory that pretends to understand and organize desire is a myth, a form of ideology created by desire to further its own ends. "The will-to-power mystique," Girard continues, "might be called the ideology of mimetic desire, if it is true that ideologies are actively engaged in furthering ends that are best furthered by not acknowledging their true natures" (74).

If Girard admires Nietzsche, it is because he had the courage to push his imperfect intellect to its most awful extremities. Nietzsche's madness symbolizes in Girard's mind the relentless commitment to a lie that becomes increasingly unsupportable as 
it grows more exaggerated. The madness of Nietzsche fuses inextricably with his genius. In "Dionysus versus the Crucified," Girard traces the collapse of Nietzsche's Dionysian mania to the Christian revelation. The essay is remarkable because Girard acknowledges for the first time the role played by Nietzsche in his own theories.

Girard's article revolves around the voice of the madman in The Gay Science and the famous passage in The Will to Power that formulates the difference between Dionysus and the Crucified. Two Nietzsches emerge, manifesting Girard's double attitude toward the thinker. ${ }^{9}$ One Nietzsche shares Girard's insights: "Nietzsche clearly saw that pagan mythology, like pagan ritual, centers on the killing of victims or on their expulsion . . ." (819). The voice of the madman in The Gay Science declares that mankind has murdered God, exposing the anthropological understanding that collective murder lies at the heart of religious and social structuration. In this insight, Nietzsche is rivaled only by the Freud of Totem and Taboo, who claims that the sacred is rooted in the collective murder of a real victim whom we call God.

The other Nietzsche represents most perfectly the inner compulsions that have led so many intellectuals to adopt "inhuman standards." For Girard, fragment 1052 of The Will to Power cuts to the heart of Nietzsche's immorality. There Nietzsche confronts the wisdom of Christ's teachings and rejects them in favor of Dionysian mania, providing modern thought with its most violent and unjust model:

Dionysus versus the "Crucified": there you have the antithesis. It is not a difference in regard to their martyrdom-it is a difference

9. If one assesses the bulk of Girard's writings, little ambivalence about Nietzsche may be found, for Girard comes out against Nietzsche at every turn. I use the idea of two Nietzsches as a rhetorical device to examine two sides of Girard's thought. Girard sees Nietzsche as the first thinker to understand the essential choice, "Dionysus or the Crucified," between the all-out violence of paganism and the nonviolence of Christianity. The problem, of course, is that Nietzsche made the wrong choice. Moreover, the emergence of the nuclear age has made the choice of purifying violence through violence impossible, which explains, according to Girard, why Nietzsche appears so very brutal to us today and why he can no longer be considered a maître à penser. 
in the meaning of it. Life itself, its eternal fruitfulness and recurrence, creates torment, destruction, the will to annihilation. In the other case, suffering - the "Crucified as the innocent one" counts as an objection to life, as a formula for its condemnation.- - One will see the problem is that of the meaning of suffering: whether a Christian meaning or a tragic meaning. In the former case, it is supposed to be the path to holy existence; in the latter case, being is counted as holy enough to justify even a monstrous amount of suffering. The tragic man affirms even the harshest suffering: he is sufficiently strong, rich, and capable of deifying to do so. The Christian denies even the happiest lot on earth: he is sufficiently weak, poor, disinherited to suffer from life in whatever form he meets it. The god on the cross is a curse on life, a signpost to seek redemption from life; Dionysus cut to pieces is a promise of life: it will be eternally reborn and return again from destruction.

Girard's reading of fragment 1052 explains that the difference between Dionysus and the Crucified is not their martyrdom but their respective interpretations. Whereas Christ condemns violence, Dionysus instigates "holy lynchings." The Crucified is the emblem of Christianity's condemnation of mankind's "violent nature." Dionysus, according to Girard, says "Yes!" to the harshest cruelty and suffering.

No one will deny the enormous ethical force of Girard's claims for Christianity, and clearly Christ's message against persecution lies at the heart of any defense that may be made for the West. It is not at all certain, however, that Nietzsche refuses the content of that message. In fact, he applies it in two startling and contradictory ways. On the one hand, the death of Dionysus Zagreus in Nietzsche's philosophy symbolizes the human tendency toward evil and violence, as does the death of Christ in Christianity. The difference is that Nietzsche is reluctant to perceive the symbol as an absolute condemnation of life and human society. He chooses Dionysus Zagreus as a symbol because mankind arises from his ashes. Nietzsche accepts, even affirms, the harsh suffering of the victim, but in no way does his affirmation preclude the struggle to overcome persecution. The show of violence is a sign of weakness in Nietzsche's mind because it implies that one can be goaded, and it must be overcome. The imperative to give style to one's character requires self-disci- 
pline, and in such self-discipline lie both the aesthetic and the ethical dimensions of Nietzsche's thought. Weak character hates and feels demeaned by discipline. Strong character attains beauty, order, and ease. It constrains itself in matters of revenge and resentment. "For one thing," Nietzsche explains in The Gay Science, "is needful: that a human being should attain satisfaction with himself, whether it be by means of this or that poetry and art; only then is a human being at all tolerable to behold. Whoever is dissatisfied with himself is continually ready for revenge, and we others will be his victims, if only by having to endure his ugly sight" (233). Whatever Nietzsche's own ability to repress violent emotion, his philosophy is designed to pass beyond human rivalry, and it requires that he reject resentment.

On the other hand, Nietzsche's embrace of Dionysus possesses a personal dimension that contradicts his philosophical disgust with human cruelty, for his choice of Dionysus encourages suffering. The difference between Christ and Dionysus is, as Girard explains, one of interpretation, but it is not the difference between victim and victimizer. Nietzsche affirms the necessity of suffering, not the right of victimizers to create suffering. Indeed, Nietzsche's relation to Judeo-Christianity emerges only when we understand that Dionysus represents first and foremost the victimary attitude. That Nietzsche is able to sign himself as either "Dionysus" or "The Crucified" exposes an identify between the two images that cannot be blamed entirely on insanity. Girard reads the oscillation as a sign of madness because he insists on the difference between Christ and Dionysus even more strongly than does Nietzsche. Untypically, in this instance, Girard reads Nietzsche's attack on Judeo-Christianity literally, as a philosophical argument, and not as a manifestation of resentment. But it is precisely at this moment that Nietzsche should be read not philosophically but in terms of his resentful desire to usurp Judeo-Christianity.

Nietzsche indeed proclaims his preference for victimizers over victims. But what does it mean to label oneself a victimizer in Judeo-Christian culture? It means finally to name oneself as the outcast of that culture, and Nietzsche's identification with the outcast exposes his desire to steal the position of the victim from 
Judeo-Christianity. Such a strategy may seem an extreme measure to attain notoriety, but Nietzsche was faced with the dilemma of trying to appear truly unique and original in a world where anyone could attain significance merely by proclaiming his or her persecution at another's hand. Possible models might have included Socrates, whose image of martyrdom had already been assimilated by Christianity along with Platonism, or JeanJacques Rousseau, who invented a secular version of the victimary attitude called Romanticism when he proclaimed himself the unanimous victim of high European culture. Rousseau's selfconfessed desire to be as self-sufficient as God already foreshadows Nietzsche's desire to achieve the status of the one unique individual in Western history. Nietzsche could have embraced the image of Christ crucified, but this choice would have meant adopting the position of an imitator, unless he could displace Christ and take his place on the cross. Nietzsche attempts this path whenever he signs himself "The Crucified," but each model is finally inadequate to his desire for uniqueness, and he makes a point of rejecting them with great pomp and circumstance.

Every model provides a direct access to the position of the victim, but Nietzsche's desire for originality and uniqueness requires that he take a less direct path. His resentment begins by placing him in a victimary attitude, and he struggles to preserve that position of significance by proclaiming with wild enthusiasm his antipathy to the majority. He takes on the image of Dionysus, the unjust, the drunken, and the violent, to perpetuate his opposition to traditional religious values. But even the choice of Dionysus betrays the desire to be a victim, for Dionysus remains of all the Olympic gods the most marginal and least acceptable. Such titles as The Antichrist and Ecce Homo appear to be as discordant as "Dionysus versus the Crucified," but each epithet exposes Nietzsche's wish to usurp the victimary attitude of Judeo-Christianity rather than to eliminate its values. Nietzsche stood not against valuation but for revaluation.

Judeo-Christian culture responded to Nietzsche's rhetoric by fulfilling his most precious desire. Nietzsche is named, following his own wishes, as the Antichrist, and as the solitary and 
grand opponent of Western Christianity. Moreover, thanks to his sister, he became associated with the Nazis, who now serve as the modern symbol of human brutality and perversion. If the Nazis symbolize everything that the West now wishes to reject, then Nietzsche makes a good candidate for the high priest of Judeo-Christianity's satanic alter ego. Increasingly, Nietzsche stands out as the one against the many, and to this position Western thought has given a singular interpretation: to be the one is to be the victim.

Everywhere is the evidence that Nietzsche achieved the special status in the Western thought that he so anxiously desired. The slogan "God is dead" has attained a popularity that remains untouched by the vulgarity of its applications, most notably because its essential vulgarity helps to heighten Nietzsche's opposition in the popular mind to the dominant values of the West. Within intellectual circles, Nietzsche is either ferociously denounced or strongly defended, but neither reaction alters his marginal status. His detractors call him a proto-Nazi or a madman and demand his expulsion from the philosophical canon. His proponents, especially of late, do not contest his madness, but defend it as an example of fierce individuality, as a harbinger of the counterculture, or as a call for a titillating freedom from rationality. Nietzsche's defenders and detractors end by sharing the same vision of their subject. The preferred image of the broken Nietzsche, sitting in a catatonic stupor, his eyes vacant and moustache overgrown, presents the same model of weakness and impoverishment to modern thought that Nietzsche himself ascribed to the icon of the crucified Christ.

Girard senses that Nietzsche is a victim of himself and of modernity, but it has never softened his attack on the Antichrist. Rather, Girard remains with the philosophical issues, and he understands the competition between Nietzschean and Christian philosophy only too well. In fact, he bases his attack on the opposition invented by Nietzsche. Nietzschean thought is "pagan" insofar as it views life as a means to knowledge. Christian thought condemns life. "Since all human culture is grounded in this collective violence," Girard writes, "the whole human race is declared guilty from the standpoint of the gos- 
pels. Life itself is slandered because life cannot continue and organize itself without this type of violence" (823). Note that Girard is repeating Nietzsche's view of Christianity not to debunk it but to explain why this world fails.

In Girard's estimation, pious efforts to exonerate Nietzsche or to represent him as a teacher of ethics are misguided. Such efforts must fail, however, not because Nietzsche's madness cannot be separated from his genius but, apparently, because the knowledge of desire cannot be achieved by the human intellect without the intervention of sublime wisdom. Yet Girard's work constantly returns to the idea that the message of Christ has so far managed only to hobble our murderous drives, menacing to turn them into "a fierce monster that now threatens to devour us all" (828). We cannot reach the truth of desire and violence without Christ, and our nature may make it impossible to grasp his message. The dark unintelligibility of desire promises to cast in shadow the light of Christ. The conclusion of Girard's "Dionysus versus the Crucified" ends with the words of Nietzsche's madman proclaiming the distance between our deeds and our consciousness of them. Human beings by definition suffer a fatal birthright of ignorance with regard to their own violence, and as such, the murderers of God do not understand their own act: "This deed is still more distant from them than the most distant stars-and yet they have done it themselves" (835).

Although many would call Girard an extremist, he is not a nihilist. The ending of "Dionysus versus the Crucified" demands comparison with the last words of Le Bouc émissaire, Girard's book on primitive mythology and the Bible, where a different message is given. The words present a warning, fatalistic in meaning but not deprived of hope. Human society is in crisis, but it can be saved through forgiveness: "All violence from now on reveals what the passion of Christ reveals, the idiotic birth of bloody idols, of all the false gods of religions, of politics, and of ideologies. The murderers nevertheless believe that their sacrifices are virtuous. They too know not what they do, and we must forgive them. The time has come for us to forgive each other" (295; my emphasis). The similarity between the two con- 
clusions is all the more startling because their messages are so contradictory. One denies that we might understand our nature; the other offers the possibility of survival in forgiving ourselves through others. Apparently, the guilt that Christianity casts on life can be abated if we forgive the murderers and affirm everyone's potential for violence.

Girard's comparative reading of Freud, Dostoevsky, and Nietzsche, "The Underground Critic" in To Double Business Bound, reproduces more economically the same contradictory view of knowledge and desire. Once again, Girard begins by giving a pessimistic description of human desire: "The more desire learns about itself, the more self-defeating it becomes" (39). The essay then gives a detailed account of desire and concludes with an attack on those who would deny the value of the human. Girard's final remarks defend the great literary works against "waning dogmatisms" and ask that we give the floor to those writers "who are capable of going much farther than has ever been gone toward the understanding of the relations of desire" (60).

Girard's contradictory positions on desire are embodied in the shift between his two Nietzsches. One Nietzsche reveals the role of desire and violence in social organization; the other remains the dupe of his own desires and lives in the blackness of ignorance. Remarkably, the same opposition can be found in Nietzsche's own descriptions of the two kinds of willing. The contradictions, however, do not follow from madness or from some inherent limitation of the religious mind. There is no reason to follow current fashion and assert the mutual incompatibility of either desire and knowledge or religion and thought. Indeed, the greatest insights of anthropology have revealed that religion is a form of social thinking. The expulsion of religion today is based not on its supposed irrationality but on the ethical claim that religion incites rivalry and aggression. The movement of modern intellectual atheism derives in part from the perception that religion, more than anything else, excites violent opposition toward competing opinions and arguments. But there can be no reason for attacking religion alone on such grounds, especially when the current intellectual climate holds 
that any form of belief may provide the justification for argument and violence. The expulsion of religion for its apparent narrowness and intolerance repeats the crime of which modern thought accuses religion.

The contradiction in Girard's theory of desire is rather a sign of his humanism. Where Girard might perfect his theology by positing the existence of grace to explain the occasions on which individuals, despite their nature, understand Christ's message of nonviolence, he becomes noticeably silent on religious issues and affirms instead the values of humanism and anthropological science. ${ }^{10}$ The absence of a theory of grace returns Girard to the power of human understanding. Unlike the French Nietzscheans, however, he does not return because it is impossible to move beyond the self within language; rather, he returns because he does not wish in the final analysis to use his theology to negate humanism. In one of his most severe attacks on the French Nietzscheans, "Delirium as System," Girard faces a theory of desire not unlike his own. Deleuze and Guattari posit the existence of a truly unconscious and paradoxical desire, and Girard reacts fiercely against the idea that the relations of desire might be unknowable: "If true desire is unconscious and still crushed by repressive codings, even in capitalism, how do the two authors know it exists?" (84). The violence of Girard's opposition to the French Nietzscheans on this point exposes his own internal contradictions, but, more important, it serves to stress the crucial role that he wishes to give to human intelligence in the revelation of violent desires. Girard's religious thought provides a means to transcend human understanding, but he does not always follow its path. He seems to prefer balancing on the brink of contradiction to giving up the possibility of an anthropology, and in that preference he comes closest to being a disciple of Nietzsche.

In Nietzsche, the tragedy of mankind lies in the fact that imperfection should exist at all, that imperfection returns eternally,

10. Grace appears only as a metaphor in Girard's thought, and to my knowledge in only one place. At the conclusion of Deceit, Desire, and the Novel, Girard contends that "conversion in death should not seem to us as the easy solution but rather an almost miraculous descent of novelistic grace" (310). 
not as an ineluctable blindness but as the thousand scandals to be overcome as individuals face themselves and each other. Nietzsche learns from Greek tragedy to affirm life in spite of suffering and cruelty. The Birth of Tragedy describes tragic drama as the mirror in which the Dionysian man contemplates himself, but the mirror is hardly narcissistic. Tragedy illuminates the absurdity of belief, the desire for revenge, and the bloody foundations of social existence. It portrays the human struggle to affirm life in spite of its horrors, and the beauty of this affirmation is the only hope for our future.

Tragedy discloses the truth of the human situation in the social world, and Nietzsche uses it as the basis of his psychology. The one significant idea that the existentialists took from Nietzsche, despite their odd emphasis on the absurdity of existence, was the profound impact of the tragic on the problem of knowledge. Knowledge in Nietzsche's philosophy is supremely relational, which does not mean that it is relative. Fear founds courage. Comedy insinuates itself into tragedy. Lies beget truth. The point is that knowledge exists not in itself but in relations. The tragedy of history, which envisions mankind's bloody past, impotent present, and tenuous future, promotes a deep pessimism, but it also teaches us to search for knowledge in life and not beyond it. Whence Nietzsche's happiest principle: "Life as a means to knowledge" (GS 255). The wisdom of tragedy is the necessity of not refusing that life.

The present generation of Nietzscheans denounces the search for a knowledge of humanity. For them, "man is dead," and the quest for knowledge cannot be separated from the thirst for power and blood. They point knowingly to Nietzsche's own critique of the will to knowledge and embrace a philosophical nihilism. Some go so far as to deny that Nietzsche ever harbored the desire to know anything, recalling his theory that truth is nothing but a figure of speech. Those who are honest enough to confess that Nietzsche believed in the possibility of knowledge also end by renouncing the search on the basis of modern theories of desire. Nietzsche may have believed in the philosophical possibility of knowledge, they admit, but his own desirous na- 
ture placed it beyond his powers. Here Nietzsche's final madness appears as the prize given to one who dares to question his own desires and unconscious strivings.

The opposition between knowledge and desire has become a cliché of modern thought, and it is perhaps the greatest threat to ethics today. It reproduces, even among atheists, the old Christian distinction between the worlds of the flesh and of the spirit. At first glance, Nietzsche emerges as the greatest enemy of this distinction. He fought courageously to bestow upon humanity the strength of will and intellect necessary to acquire a knowledge of its own emotions. But Nietzsche's project fell short, not because the search for knowledge necessarily ends in madness but because he was unable to free himself from his resentful desire to imitate Judeo-Christianity. In his imperative to overcome mankind, Nietzsche duplicates the same idea of human inadequacy and weakness held by his rival. Nietzsche's call for an overman and the Judeo-Christian belief in a messiah obey the same impulse, the impulse to bring in a conscience other than human to provide ethics with an intelligent foundation. Girard's divine revelation of desire and violence also appears at moments to rely on the tragic labor of human intelligence, but it risks concluding, as does Nietzsche's work, at the point where the self succumbs to its own scandalous nature. Nietzschean philosophy and Judeo-Christianity are finally inadequate for an understanding of ethics, although they may be necessary to its evolution, because they place ethical models beyond the scope of the human community and its representations. Even if such models are only projections of internal social and ethical attitudes, as Durkheim argued, the essentially unconscious nature of the projection stands in the way of the more advanced ethical conception deriving its force from the broad awareness on the part of the community that the human community is itself the only solution to its problems.

Both Girard and Nietzsche discover the drama where the idea of humanity confronts its tragic limitations. The modern perception of desire, whether it appears in the form of Freudian, mimetic, or resentful theory, has denied to human beings the 
158 The Ethics of Criticism

degree of self-consciousness necessary to conceive of an ethics. If we listen to these modern theorists of desire, mankind may only hope to attain a knowledge of ethics unconsciously, or as a consciousness other than itself. Perhaps the time has come to stop searching for this other consciousness and return to the study of humanity and its ethics. 